\title{
The Lichens of the Mountain-Taiga Belt of the Ergaki Nature Park
}

\author{
Olga A. Zyryanova* \\ Khakas State University named after N.F. Katanov, 90 Lenin St., 655000, Abakan, Russia
}

\begin{abstract}
The article presents the data on the species composition of lichens in the mountain-taiga belt of the Ergaki Nature Park. The taxonomic list of lichens is represented by 288 taxa of a species rank belonging to 89 genera and 39 families. The largest number of species is characterized by the crustose life form. Mesophytes and epiphytes are predominant in the terms of ecological substrate.
\end{abstract}

\section{Introduction}

The natural park of regional importance - Ergaki located in the Western Sayan occupies several districts of Krasnoyarsk Territory at once, specifically Karatuzsky, Ermakovsky and Kuraginsky districts. Due to its length it covers various high-altitude mountain belts.

The studies on the species composition of lichens were conducted in the vicinity of the Tushkanchik cordon, which is located according to the paper of M.V. Bocharnikov in the mountain-taiga belt of the Western Sayan [1].

\section{Material and methods}

The materials for the study include the herbarium specimens of lichens collected by the authors in the vicinity of the Tushkanchik cordon with the use of route method. The material collection and herbarization was performed using the common method described in the second edition of Identification Guide to Lichens of the USSR "Morphology, Systematics and Geographical Distribution" [2]. Around 360 herbarium envelopes were collected and then processed in the Laboratory of the Khakas State University named after N.F. Katanov with the use of the microscope Mikromed-1 and binocular loupe MBS-2 with $10 \% \mathrm{KOH}$ solution. In order to identify the materials "Identification Guide to Lichens of the USSR" [3-6] and "Identification Guide to Lichens of Russia" [7-11] were used. Some types were specified in work of R. Santesson et al. [12]. The life forms and ecological groups were identified on the basis of the personal observations of the authors and according to the literary sources [13].

\section{Results and discussion}

\footnotetext{
*Corresponding author: 으_z_zyryanova@mail.ru
} 
As a result of the studies it was established that the lichen flora of the mountain-taiga belt of the Ergaki Nature Park in the vicinity of the Tushkanchik cordon is represented by 288 species belonging to 89 genera and 39 families.

The average number of species in a family is 7.38. As shown by taxonomic analysis the lichen flora is represented by 10 dominant families (76.74\%), among which the highest level of diversity belongs to the family of Parmeliaceae Zenker (68 species, $23.61 \%$ ). The further families located in the descending order include Cladoniaceae Zenker (50 species; 17.36\%), Lecanoraceae Körb (27 species, 9.38\%), Rhizocarpaceae M. Choisy ex Hafellner (14 species, $4.86 \%$ ), Physciaceae Zahlbr and Stereocaulaceae Chevall. (12 species; $4.17 \%$ ), Hymeneliaceae Körb, Peltigeraceae Dumor and Umbilicariaceae Chevall. (10 species, $3.47 \%$ ), Pertusariaceae Körb.ex. Körb. (8 species, $2.78 \%$ ). Among the families not included in the dominant category there are Porpidiaceae Hertel et Hafellner ranked 11 th and having 6 species, the family of Lecideaceae Chevall having 5 species, Bacidiaceae W. Watson, Nephromatacaea Wetm.ex J. David et D. Hawksw. and Roccellaceae Chevall. having 4 species, 6 families having 3 species each, 7 families having 2 species each and 11 families having 1 species each.

89 genera found in the lichen flora. The average number of species in a genus is 3.24. The level of species diversity exceeding average can be found in 18 genera uniting 191 species $(66.32 \%)$. The remaining 21 genera account for 97 species $(33.68 \%)$, among which 3 species are represented by 9 genera $(9.38 \%), 2$ species by 12 genera $(8.33 \%)$ and 1 species by 46 genera $(15.97 \%)$.

The spectrum of life forms is characterized by the predominance of the crustose lichens (125 species, $43.40 \%$ ). This thallus cannot be separated from the substrate where it grows without damaging it. As can be seen, for example, in Amandinea punctata (Hoffm.) Coppins et Scheid., Caloplaca holocarpa (Hoffm. Ex Ach.) A. E. Wade, Aspicilia laevata (Ach.) Arnold and others. The fruticose lichens (89 species, 30.90\%) and foliose lichens (74 species, $25.69 \%$ ) are less represented. Among the fruticose lichens the most common are Cladonia arbuscula (Wallr.) Flot.ssp. mitis (Sandst.) Ruoss, $\mathrm{Cl}$. amaurocraea (Flörke) Schaer., Cl. stellaris (Opiz) Pouzar et Vêzda, Bryoria implexa (Hoffm.) Brodo et D. Hawksw., Usnea glabrescens (Nyl. ex Vain.) Vain., U. longissima Ach., al eds.; while the foliose lichens are represented by Hypogymnia vittata (Ach.) Parrique, H. physodes (L.) Nyl., Peltigera polydactylon (Neck.) Hoffm. Melanelia septentrionalis (Lynge) Essl., Parmelia omphalodes (L.) Ach., P. sulcata Taylor and others.

While establishing ecological groups of lichens in the vicinity of the Tushkanchik cordon, we used the work by N.V. Sedelnikova [13-14]. Seven ecological groups were identified: mesophytes, xerophytes, xeromesophytes, xerocryophytes, cryophytes, psychrophytes and hygrophytes. The predominant role belongs to the mesophytic lichens (209 species, $72.57 \%$ ). These are lichens that can be found in places with fairly moderate humidity, usually located on the shaded rocks or at their base. These include the lichen species such as Aspicilia lapponica Hue, Physcia phaea (Tuck.) Thoms., Squamarina cartilaginea (Witt.) P. James and others. The cryophytes rank second in terms of the species number (which makes 25 ). They account for $8.68 \%$ of the total number of species. These are the species of the coldest and driest habitats of the high-mountain belt. For example, Lecidea auriculata Th. Fr., Miriquidica leucophaea (Flörke et Rabenh.) Hertel et Rambold and others. The xerophytes rank third (23 species, $8.09 \%)$. This group includes mainly those lichens, which are abundant in the conditions of dry and warm climate regimes. The examples include such species as Lecanora frustulosa (Dicks.) Ach., L. argopholis (Ach.) Ach., Protoparmeliopsis muralis (Schreb.) M.Choisy and others.

Based on the available data on the confinedness to the substrate in the studied area, the epiphytes hold a leading position (117 species, $40.63 \%)$. They include, for example, Ramalina pollinaria (Westr.) Ach., Rinodina sophodes (Ach.) A. Massal., Physcia tenella 
(Scop.) DC. and others. The group of epilithophytes is the least presented group of lichens (93 species, 32.29 \%). For instance, Porpidia cinereoatra (Ach.) Hertel et Knoph, Physcia caesia (Hoffm.) Fürnr., Lasallia pensylvanica (Hoffm.) Hano and others. The soil cover species are represented by the epigeal lichens (78 species, $27.08 \%$ ) mainly from the genera of Cladonia, Peltigera and Stereocaulon.

The geographical analysis of lichens of the studied area was carried out by the principle of zonality based on the works of N.V. Sedelnikova [13-14]. All types are distributed into 7 geographical together with 13 types of natural habitats distributed in accordance with the nature of latitudinal placement of species (tab. 1).

Table. 1. Distribution of lichens of a mountain-taiga belt of the Ergaki on geographical elements and types of areas

\begin{tabular}{|l|c|c|c|c|c|c|c|c|c|c|c|c|c|c|}
\hline \multirow{1}{*}{$\begin{array}{c}\text { Geographical } \\
\text { elements }\end{array}$} & \multicolumn{10}{|c|}{ Types of areas, number of species } & Total \\
\cline { 2 - 19 } & 1 & 2 & 3 & 4 & 5 & 6 & 7 & 8 & 9 & 10 & 11 & 12 & 13 & number \\
\hline Arctalpine & - & 1 & 11 & 12 & 7 & 9 & - & - & - & - & - & - & - & 40 \\
\hline Alpine & - & - & - & - & - & - & - & - & 1 & - & - & - & - & 1 \\
\hline Hypoarctmontan & - & 2 & 14 & 17 & 9 & 3 & 1 & - & - & - & - & 1 & & 47 \\
\hline Montan & - & 4 & 10 & 17 & 17 & 4 & - & 1 & - & - & - & 3 & 1 & 57 \\
\hline Boreal & - & 4 & 23 & 21 & 38 & 14 & - & - & - & 1 & - & 1 & - & 102 \\
\hline Nemoralis & 1 & 3 & 2 & 10 & 10 & - & - & - & - & - & - & - & - & 26 \\
\hline Steppe & 1 & 2 & 1 & 5 & 5 & - & - & - & - & - & 1 & - & - & 15 \\
\hline \multicolumn{1}{|c|}{ TOTAL: } & 2 & 16 & 61 & 82 & 86 & 30 & 1 & 1 & 1 & 1 & 1 & 5 & 1 & 288 \\
\hline
\end{tabular}

Note. Types of natural habitats: 1 - Asian, 2 - Euro-Asiatic, 3 - Euro-American, 4 - Holarctic, 5 Pluriregional, 6 - Holarctic-Notarctic, 7 - Euro-African, 8 - Submediterranean, 9 - Central Asian, 10 - Asian-Caucasian, 11 - African-Asian, 12 - American-Asian, 13 - American-Asian-AfricanAustralian.

The geographical analysis of lichens demonstrated the predominance of the boreal geographical element (102 species, $35.4 \%)$ with the inclusion of montane $(57$ species, $19.8 \%$ ) elements. Among the species of boreal element the most common are epiphytic lichens Hypogymnia physodes (L.) Nyl., H. vittata (Ach.) Parrique, Usnea. glabrescens (Nyl. ex Vain.) Vain., U. longissima Ach., Bryoria fuscescens (Gyeln.) Brodo et D. Hawksw., Evernia mesomorpha (Müll. Arg.) Du Rietz, and from montane - Lecanora varia (Hoffm.) Ach., Lecidella elaeochroma (Ach.) M. Choisy, Buellia disciformis (Fr.) Mudd.

Analyzing the type of habitat one can say that the pluriregional (86 species, $29.9 \%)$ and holarctic ( 82 species, $28.5 \%$ ) lichens are predominant.

The studied area comprised 4 species of lichens included in the Red Book of the Krasnoyarsk Territory[15]: Lobaria pulmonaria (L.) Hoffm., Lobaria scrobiculata (Scop.) DC., Nephromopsis laureri (Kremp.) Kurok., Usnea longissima Ach.

\section{Conclusion}

Thus, the lichen flora of the studied territory is basically boreal, as evidenced by the high grade of the dominant families, the biomorphological and ecological features of the species and the geographical analysis.

\section{References}

1. M.V. Bocharnikov, The geography of Botanical diversity of the Western Sayan mountains, Diss. (Moscow, 2012) 
2. A.N. Oksner, Identification Guide to Lichens of the USSR, 2 (Science, Leningrad, 1974)

3. Identification Guide to Lichens of the USSR, 1 (Science, Leningrad, 1971)

4. Identification Guide to Lichens of the USSR, 3 (Science, Leningrad, 1975)

5. Identification Guide to Lichens of the USSR, 4 (Science, Leningrad, 1977)

6. Identification Guide to Lichens of the USSR, 5 (Science, Leningrad, 1978)

7. Identification Guide to Lichens of Russia, 6 (Science, St. Petersburg, 1996)

8. Identification Guide to Lichens of Russia, 7 (Science, St. Petersburg, 1998)

9. Identification Guide to Lichens of Russia, 8 (Science, St. Petersburg, 2003)

10. Identification Guide to Lichens of Russia, 9 (Science, St. Petersburg, 2004)

11. Identification Guide to Lichens of Russia, 10 (Science, St. Petersburg, 2008)

12. O.E. Eriksson, D.L. Hawksworth, Outline of the Ascomycetes (Wallingford, UK, 1998)

13. N.V. Sedelnikova, Lichens of Altai and Kuznetsk highlands: Summary of flora (Science, Novosibirsk, 1990)

14. N.V. Sedelnikova, The Lichens of the Western and Eastern Sayan (Science, Novosibirsk, 2001)

15. Red Book of the Krasnoyarsk Territory (Krasnoyarsk, 2009) 